\title{
PROPOSAL THE APPLICATION OF DMAIC TOOLS AND VALUE STREAM MAPPING UNDER THE PERSPECTIVE OF THE LEAN PHILOSOPHY FOR PROCESS IMPROVEMENT: A CASE STUDY
}

\author{
Jefferson de Souza Pinto ${ }^{1}$, Luan Aoki Schuwarten ${ }^{2}$, Gilberto Cassoli de Oliveira Júnior ${ }^{3}$, Olívio Novaski ${ }^{4}$ \\ 1 University of Campinas (UNICAMP) and Federal Institute of Education, Science and Technology of São Paz̧,lo (IFSP); \\ 2 Federal Institute of Education, Science and Technology of São Paulo (IFSP); \\ 3 Federal Institute of Education, Science and Technology of São Paulo (IFSP); \\ 4 University of Campinas (UNICAMP)
}

\begin{abstract}
After a recent merger, the in vitro diagnostic equipment trade company in Brazil, study object, faces difficulties for its logistics flow. The work proposes the application of the DMAIC tools, contained in the context of the six sigma, and Value Stream Mapping (VSM) under the lean philosophy perspective in order to identify the focus of waste that can be improved, corroborating with lean thinking. Unlike the common application of VSM, used in manufacturing processes, this study has its application in a service chain. From the Methodology point of view, the case study uses a qualitative approach, having as strategy the bibliographics with a descriptive and explanatory objective. Additionally, it is delineated based on the DMAIC cycle to establish the industrial overview and method of conducting the process study, and consequently, the influence on the management by the guidelines and their impact on the management of the work routine. Thus, the VSM application is presented to control the flow of distributed inventory parts with the current and future process state maps. Finally, the analyzes show the results obtained with the reduction of the waste, from the centralization of the company's inventory.
\end{abstract}

Keywords: Lean Tools; Value Stream Mapping; Six Sigma; DMAIC; Process Improvement. 


\section{INTRODUCTION}

The scenario of business organizations, regardless of the area of activity of the business, permeates a dynamic and very competitive reality, with no defined economic boundaries, with constant fluctuations in terms of market demand, increasingly demanding clients and increasingly restrictive local legislations in what concerns to market, quality, environment and workers (Oliveira, 2013; Shingo, 1996; Oliveira et al., 2011).

With broad-spectrum reach to directly influence human behavior, globalization has spurred the emergence of a relentless global market scenario. In this sense, in today's competitive world, a kind of natural selection takes care of those organizations that have not prepared themselves to achieve established goals. This competitiveness in the various economic sectors has required organizations to seek innovations in their management models in order to continuously increase their ability to respond to the unexpected crises of the world market or to the opportunities that are generated by them (Carvalho, 2011; Leite et Filho, 2009; Cruz et Monteiro, 2015).

Succeeding in this context requires that organizations be as dynamic as the reality. In this perspective, the adoption of lean practices presents itself as an interesting tool for the competition. As a result, by adopting process improvement practices - mechanisms to obtain more agile flows, optimization of internal resources and elimination of wastages to raise revenue - the companies have an efficacious solution to reach a level of excellence and competitive advantage (Tapping et Shuker, 2010; Carpinetti et al., 2011; Shingo, 1996; Bento et al., 2016).

However, empirically, conveying the strategic design of the business to operational actions in an organization is not a simple task. Depending on the degree of maturity, it is observed that companies present substantial difficulty in diagnosing and identifying strengths and weaknesses of management (Leite et Filho, 2009).

On the other hand, by redirecting the focus to an analysis based on the application of lean methods and tools, in order to ensure the alignment of strategic and organizational issues with processes and operations, a considerable improvement can be achieved in the cultural and organizational environment of the companies (Calado, 2011; Oliveira, 2013).

Based on this assumption, through a case study, this work's objective is to apply the tooling framework of the Lean and Six Sigma philosophy, in order to map the flow of value and improve the control process of entry and exit of parts, being applied in a company that markets equipment for the in vitro diagnostics market in Brazil.

\section{BIBLIOGRAPHIC REVIEW}

\subsection{Lean Thinking}

From a historical perspective, the Toyota Production System or, more recently, the Lean Production System, from the second half of the twentieth century, appears to include a new set of philosophies and strategies within the inter-capitalist scenario, causing a rupture in concepts and management models of the period (Corrêa et Gianesi, 1993; Shingo, 1996; Ghinato, 1997; Slack et al., 2009; Holweg, 2007; Calado, 2011; Pacheco, 2014).

As observed by Calado (2011) and Pachedo (2014), the term Lean was originally proposed in the book "The Machine that Change the Word" by Womack et al. (1992), where became evident the superiority of the model adopted by Toyota as well as its success in the Japanese industry (Ghinato, 1997; Holweg, 2007; Calado, 2011; Pacheco, 2014).

Thus, the conceptions of Shah et Ward (2003) define the Lean philosophy as a multidimensional approach that encompasses a variety of management practices. Focused on the flow of activities that add value and that aim to eliminate waste, the practice of Lean aims to better meet customer demand. Additionally, Shingo (1996) argues that the central objective of lean manufacturing is to enable organizations to respond rapidly to the constant fluctuations in market demand from the effective reach of the main dimensions of competitiveness: flexibility, cost, quality, service and innovation (Shingo, 1996; Shah et Ward, 2003; Machado, 2006, Bento et al., 2016).

From the definitions presented, it should be pointed out that, although Lean is tooling framework initially emerged in a production and manufacturing scenario, more recently it is possible to verify that there are variants of the philosophy with several applications, corroborating the definition of Shah et Ward (2003).

In order to verify the different approaches of the Lean philosophy, the state of the art together with a systematic review allowed highlighting what the authors have discussed on the subject. Thus, Table 1 summarizes the conceptions of the authors studied as well as their respective approaches on the lean mentality.

The study on the authors presented in Table 1 shows, initially, the application of lean in the manufacturing context. However, with the maturity of the approach over the years, lean philosophy has been gaining strength in other fields of application, for example, in product development, innovation, processes, and, more recently, practices for sustainability (Holweg, 2007; Pacheco, 2014). 
Brazilian Journal of Operations \& Production Management

Volume 14, Número 4, 2017, pp. 556-566

DOI: 10.14488/BJOPM.2017.v14.n4.a11

Table 1. Approaches to the Lean philosophy

\begin{tabular}{|c|c|}
\hline Approaches of the Lean Thinking & Authors \\
\hline $\begin{array}{l}\text { Lean Production / Lean } \\
\text { Manufacturing / Lean } \\
\text { Management }\end{array}$ & $\begin{array}{l}\text { Ohno (1997); Shingo (1996); Monden } \\
\text { (1998); Schonberger (1982); Feld (2001); } \\
\text { Dennis (2002); Liker et Meier (2007); } \\
\text { Bicheno (2004); Womack et Jones (2003); } \\
\text { Keyte et Locher (2004); Pettersen (2008) }\end{array}$ \\
\hline $\begin{array}{l}\text { Lean Product Development /Lean } \\
\text { Product and Process Development } \\
\text { / Lean Innovation }\end{array}$ & $\begin{array}{l}\text { Hoppmann et al. (2011); Morgan et Liker } \\
\text { (2006); Schuh (2013); Womack et al. } \\
\text { (1992); Ward et Sobek (2014) }\end{array}$ \\
\hline Lean and Green & $\begin{array}{l}\text { Caldera et al.(2017); Fliedner et Majester } \\
\text { (2010);Garza-Reyes (2015); Chiarini } \\
\text { (2014); King et Lenox (2001) }\end{array}$ \\
\hline
\end{tabular}

Source: The authors' own (2017).

On the basis of the exposed arguments, it becomes apparent that the lean mentality sensitizes an extensive field of use. Thus, the present work will make use of the lean philosophy in order to map and improve the flow of value of the control process of pieces that are sent to the field by the company under study, according to Fitzsimmons et Fitzsimmons (2014), who reinforce the application transposition of lean manufacturing mentality to a service environment.

\subsection{Value Stream Mapping - VSM}

According to the definition adopted by Calado (2011), Value Stream Mapping (VSM) is a visual tool used to map the flow of value of a process or operation, whose objective is to eliminate waste and identify opportunities (Calado, 2011; Wee et Wu, 2009; Rother et Shook, 2012; Slack et al., 2009).

Thus, the Sundar et al. (2014) conception demonstrates that the flow of value can be understood as the set of all activities, including those that aggregate or not add value, required to transform raw material into finished product (Sundar et al., 2014; Rahani et Al-Ashraf, 2012; Rother et Shook, 2012).

As noted by Womack et Jones (2003), the essence of VSM is to identify and eliminate waste. Moreover, Kerzner (2011) raises the seven wastes that should be the focus of a process of continuous improvement from Shingo's point of view (1996). Thus, to better understand the concepts presented, it is necessary to punctuate the wastes, which are: overproduction, wait, excessive transport, inadequate processing, stock waste, movement and defects.

Because the VSM tool provides reliable qualitative analysis, it also provides the project scope by defining the current and future state of the process. In this way, the holistic character of the tool allows, when applied methodically, providing improvements to the system, allowing mitigating the impacts of wastes (Womack et Jones, 2003; Matthew et Spedding, 2010).
According to Rother et Shook (2012), VSM is, in essence, a language, and like any new language, the best way to learn to map it is the exhaustive practice. Still under the authors' conception the initial stages of VSM are presented in Figure 1 , in which the design of the future state as an object to project and introduce a lean stream of value is highlighted.

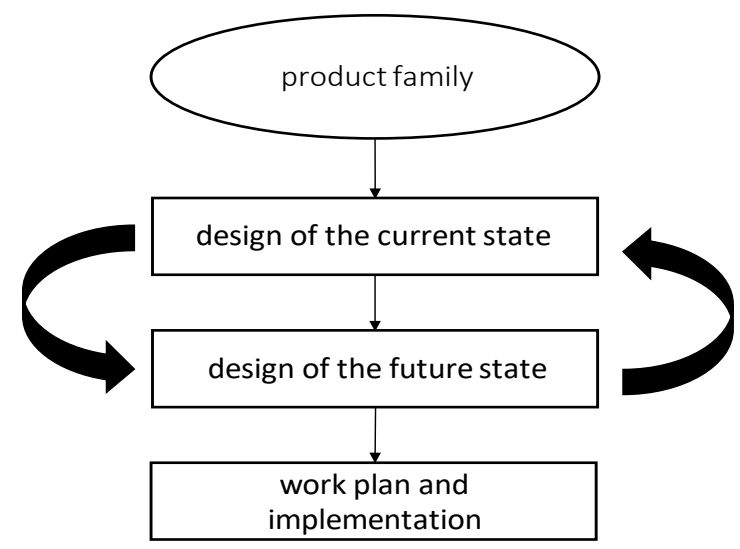

Figure 1. Initial Steps of Value Stream Mapping Source: Rother et Shook (2012, p.9).

In this sense, the value stream mapping is an efficient tool to identify the opportunities to apply lean techniques for process improvements. In view of this precept, the objective of VSM application at work is to diagnose and identify strengths and weaknesses of management in a process of logistic flow in the company under study.

\subsection{Six Sigma}

Historically, the research's points to the concepts created by Motorola during the 1980s. Motorola engineers such as Bill Smith, known as the first to use the term sigma, and Bob Galvin who acted as the leader of the engineers of the time were identified as the precursors of the Six Sigma methodology (Matthew et Spedding, 2010; Rezende Júnior, 2015).

However, Pacheco (2014) asks about its true emergence by quoting Sharma (2003), who states that its development was applied to a solution of business problems by Mikel Harry.

From the statistical point of view, the term sigma is a measure of intrinsic variability of a process defined by standard deviation. In addition, it arises from the relationship between the variation of a process or product and the requirements of the clientes (Pacheco, 2014; Rezende Júnior, 2015). The methodology objective is to reduce defects by means of previous internal or external process definitions, leading the system to 3.4 defects for every million opportunities (Kerzner, 2011; Matthew et Spedding, 2010). 
The six sigma process generally follows the principles laid down in the philosophy of the DMAIC cycle (Dahlgaard et Dahlgaard-Park, 2006). Kerzner's (2011) approach reveals that the application of the DMAIC cycle in six sigma implementation programs aims to identify the root causes of defects.

In this sense, in a treatment analogous to the Deming PDCA Cycle, the DMAIC tool presented in Figure 2, in five distinct stages, aims to: define, measure, analyze, improve and control the design of the future state of the process, corroborating the conception of Rother et Shook (2012).

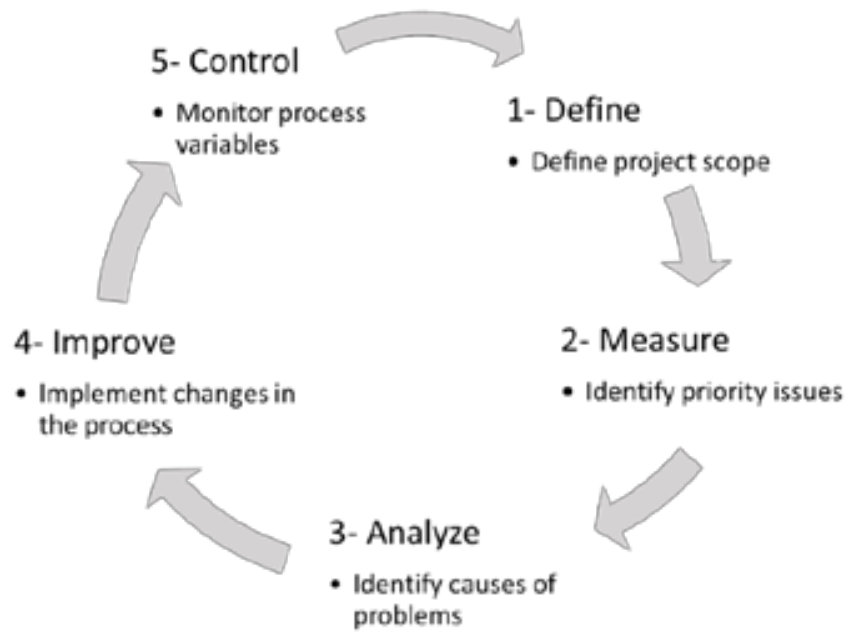

Figure 2. DMAIC cycle

Source: Adapted from Rezende Júnior (2015).

In considering this perspective, using the DMAIC tool, based on the six sigma philosophy aims to outline the improvement points in the operational scope, as shown in Figure 3, which seeks to highlight the application gap. Therefore, the role played by the six sigma as an interface between the operation level and operation improvement is highlighted in the figure. Thus, the management method presented will serve as a model for conducting the analyzes of the proposed problem.

Falconi (2013) deals with the management method from the point of view of the philosophy of the PDCA Cycle. As a way of solving problems, the proposed managerial approach encompasses the conception of systemic thinking with interconnected factors in the sense that everything that is done at any level of the organization to improve it results in changes in its standard operating procedures. In addition, in raising the positive points of the method, it reinforces that the use of tools and technical resources improve it continuously.

Therefore, Figure 3 presents the interconnected actions that define the Management System Model and its subsystems: Strategic Management, Guidelines Management, Project Man- agement and Routine Management. However, it is important to emphasize that the work will focus on Management by the Guidelines and the relationship with Routine Management.

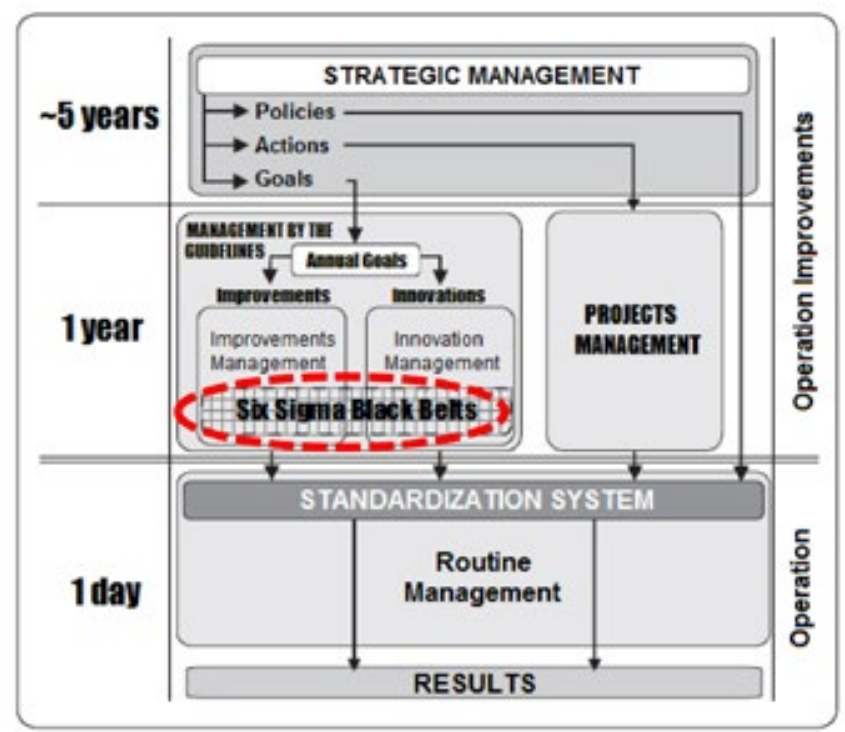

Figure 3. Management system model Source: Falconi (2013, p.30).

Finally, from the aforementioned conception, this work aims at applying the six sigma tool as a way to interface the management actions of the guidelines that directly impact the processes of the work routine.

\section{METHOD}

According to Beuren (2006), the case study is important for gathering numerous and detailed information with a view to learning the wholeness of a situation.

Still on the case study, Gil (2016) characterized it by the deep and exhaustive study of one or a few objects in order to reach a wide and detailed knowledge of it. Therefore, the work is based on a company, object of study that acts in the field of commercialization of inputs and equipment for the in vitro diagnostic sector in Brazil.

According to Gil (2009), the case study should involve the delineation of the problem with an intensive analysis, based on the different methods or techniques of data collection. Therefore, data collection will be done based on the mapping of the value flow of a company's logistics process, as well as the observation and reports of employees directly involved with the said sector.

It is also important to highlight that, when corroborated with the conception of Hair Jr. et al. (2005) and Gray (2012), 
the case study uses the observation procedure for its construction and description, as well as the analysis of documents inherent to the process.

Cooper et Schinlder (2016) corroborate with Gil's (2009) and Beuren's (2006) conceptions that qualitative research encompasses a set of interpretative techniques, data analysis and data collection, aimed at reaching an in-depth understanding of a situation. In addition, Cooper et Schindler (2016) emphasize that trustworthiness of qualitative data with the use of rigorous methodology becomes a reliable basis for business decision making.

In this sense, in order to define the design of the research, based on the objectives, this work will be classified as a bibliographic research with descriptive and explanatory purposes, through a case study and with a qualitative approach, with a view to deepening the knowledge about the theme.

Recently restructured by a merger process, it is observed that the company has the need to adapt the process of control of parts sent to the field for customer service. As a result, it was verified the need to identify the real cause of possible restrictions in the flow of the value chain.

Through the concepts presented in the theoretical review, it is intended to apply the VSM tool to map and analyze, in detail, the steps of the process.

\section{CASE STUDY}

\subsection{Meanings about DMAIC tools}

First of all, before inserting the panorama to which this work is inserted, it is worth highlighting how the DMAIC proved to be an efficient tool for the method of conducting the analyzes of this case study. Then, it is emphasized that, by using the approaches of the cycle to conduct the analyzes, a more assertive and concise understanding about the processes was obtained.

In this sense, the tool used as a conducting method allowed enriching the way the work proposal was delineated, under the justification that the analyzes were conducted based on a tool whose effectiveness has academic proof.

As shown in Figure 2, the cycle is composed of five steps, they are: define, measure, analyze, improve and control.

Thus, when analyzing the context of the needs of the company under the aegis of the first stage, it was possible to define the scope of the project with considerable precision.
Likewise, under the support of the second stage, the priority issues, that is, the deficient processes that could be improved were identified.

Consequently, in the third stage, under a critical analysis, it was possible to raise the causes of the problems inherent in the process.

Subsequently, the fourth stage, allowed pointing out procedural changes in order to obtain improvements.

In search of results, the fifth stage, points the monitoring of the inherent variables to the process, completing the DMAIC cycle.

Finally, it is emphasized that the application of the DMAIC tool in this work goes beyond the standard context and, therefore, is not tacit. As a result, it was necessary to point out how the use of this tool is inserted in the case study, method used for conducting the analyzes.

\subsection{Overview}

This section intends to insert the context to which the tools included in the bibliographic review are applied.

For strategic reasons and, as a way to ensure a competitive market advantage, it is common for organizations to opt for the merger process rather than running the risk of having their hegemony threatened and losing their market share. Nevertheless, it is a fact that incorporation generates significant transformations in all the parties involved.

From this point of view, recently restructured by a merger process, it is perceived that the company under study needs to be improved and adjusted in some of its operational processes. In this sense, the focus of this work is the process of control of parts sent to the field for customer service.

Moreover, it should be noted that the company operates in the service industry in the in vitro diagnostics market, with emphasis on the distribution of inputs and equipment. Unlike a production process, types of processes in service operations tend to be people-based, rather than product-based.

Thus, increasing market share implies that the organization proportionally assumes greater responsibility and commitment to internal processes and operations in order to better serve customers, so the tools of lean and six sigma philosophies become preponderant to improve the process flow.

In addition, the next sections will aim to explore the use of the VSM tool for mapping the process steps. 


\subsection{Problem Description}

\subsubsection{Understanding of the logical flow}

This section is intended to explore how the steps initiate the process under study. In corroborating Falconi's conceptions (2013), the understanding of logical flow is presented as a means of synthesizing the overall understanding of the process, as well as delineating the field of application of the proposed tools.

In view of the precepts presented here, it is necessary to describe how the logistic process of sending of parts happens. However, in order to know better the problem, how it happens, how the constraint affects the flow and what should be prioritized for its solution, we establish a logical flow, which is presented in Figure 4.

The steps described below can be understood as an operational routine whose activities must respect a precedence relation, that is, an activity must be complete for another activity to start.

From a procedural point of view, the company has a service team that is responsible for responding directly to customer calls. In general, customer satisfaction occurs when field technicians are able to service the equipment in loco and in the shortest possible time.

The analysis history made by the field technicians has shown that, in most cases, the problems are solved by replacing the damaged parts; thus, there is a need for an efficient logistics process so as to serve them better.

From this perspective, the analysis of Figure 4 shows that the process consists of eight main stages. The sequencing of these stages carries the premise that the field technician has already diagnosed the customer's equipment problem as well as the part needed to solve it.

Thus, the first stage of the process consists of the reporting to the service team with the request of the part needed for the service.
Therefore, in the second stage, the services sector consults on the availability in one of the four inventories of the group companies. Each inventory is unique to the parts family, that is, each inventory stores parts of a particular line of equipment. In addition, it is worth mentioning how the geographical decentralization of the warehouses affects the process, becoming the great restriction of the flow, with reflexes in the other stages.

Because of geographic segregation, after checking the availability in the inventory - third stage - the information should be returned to the services office, where tax manipulations are done so that the shipment can be carried out. Note that there is the inconvenience in terms of information never being handled in the same place, generating considerable waste due to over-handling, as well as the overloading of functions with employees.

Subsequently, in the fourth stage, the part is sent to the technician, and this transportation can be for the whole country. Also in keeping with the segregation of inventory, it should be noted that the shipping process can be charged in two ways: as to the volume of delivery and as to the distribution of the pieces originate in more than one inventory to attend the same order.

In the first case, the excess of movement causes a greater dispersion of information, consequently, negatively impacting the volume of deliveries. In other words, logistics does not always align the most appropriate strategy for the distribution of parts that, for example, are destined to the geographically close regions. In the second case, in certain circumstances, the same request from the technician is not always attended by a single inventory, causing a waste in the distribution.

In the fifth stage, once the piece is in hand, customer service is done. The technician, in the sixth stage, is committed to return the replaced part to the remanufacturing center; the return period is seven days.

In the seventh stage, the sorting of the pieces that return from the field is performed. According to the state of

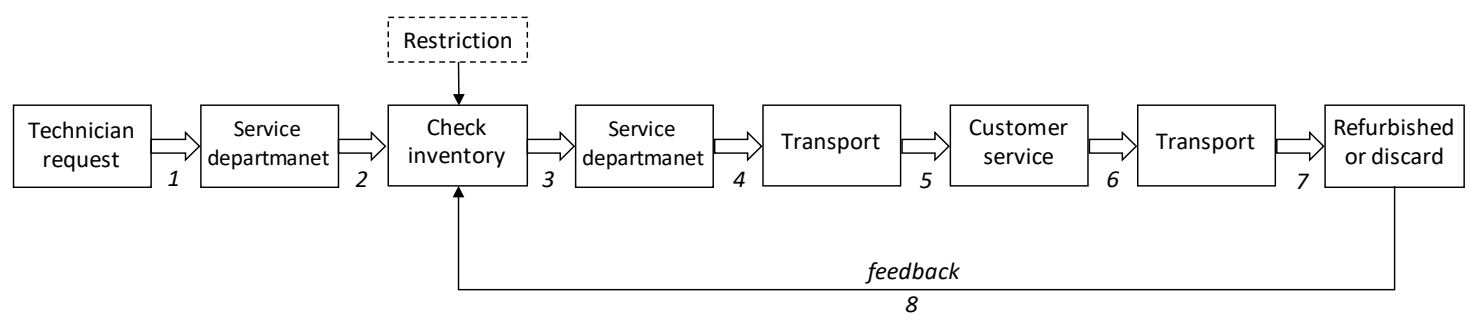

Figure 4. Logical process flow

Source: The authors' own (2017). 
the component, if it is not possible to remanufacture it, it is properly discarded; if it can be repaired, it will be repaired.

Finally, in the eighth stage, after the repair, the part becomes part of the company's stock that centralizes the repair and maintenance of parts and equipment of the group, being available to be sent to the field again.

Although the focus is on the logistical process, it is worth pointing out that there are also other operational routines that are related to the central theme of this work; however, they do not fit the proposed scope and therefore is not mentioned, as, for example, the supply chain. In addition, the work will not focus on the external routines, that is, on the return of the part to the inventory.

Thus, the next sections present the application of the VSM tool for process mapping.

\subsubsection{Current State Map}

In view of such precept, to understand the current state map presented in Figure 5, some considerations are necessary.

First, as this work is an application of a common tool in manufacturing processes, it is important that there be a convention on the meanings of the concepts employed.

Typically, in manufacturing processes, the cycle time $(C / T)$ and the chengeover time $(\mathrm{C} / \mathrm{O})$ variables are defined as the production time of a product unit and the production setup time, respectively. However, since the production scenario gives rise to a service scenario, the takt time concept will not be considered.

Thus, for the service chain, the cycle time $(C / T)$ and the exchange time $(\mathrm{C} / \mathrm{O})$ should be understood, respectively, as the time in which the execution of a process activity occurs and the time between one activity and another, that is, until the later stage begins to treat the actions of the previous stage.

Second, for the analysis of the processing time (summation of the changeover times) and the service lead time (summation of the cycle times), the times from the red highlight will not be considered, because they do not directly impact the stages of the internal process.

Thus, in order to expose the critical analysis of the map of Figure 5, information regarding the cycle time and changeover time of each step is summarized in Table 2.

Table 2. Summary of current state map times

\begin{tabular}{|c|c|c|c|}
\hline Stage & Description & Cycle time $(\mathrm{C} / \mathrm{T})$ & Changeover time $(\mathrm{C} / \mathrm{O})$ \\
\hline 1 & Technician request & $2 \mathrm{~h}$ & $40 \mathrm{~min}$ \\
\hline 2 & Service departmanet & $30 \mathrm{~min}$ & $1 \mathrm{~h}$ \\
\hline 3 & Check inventory & $4 \mathrm{~h}$ & $1 \mathrm{~h}$ \\
\hline 4 & Service departmanet & $30 \mathrm{~min}$ & $3 \mathrm{~h}$ \\
\hline 5 & Transport & Variable time & $1 \mathrm{~h}$ \\
\hline 6 & Customer service & $8 \mathrm{~h}$ & 7 days \\
\hline 7 & Transport & Unvalued & Unvalued \\
\hline 8 & Refurbished & Unvalued & Unvalued \\
\hline
\end{tabular}

Source: The authors' own (2017).

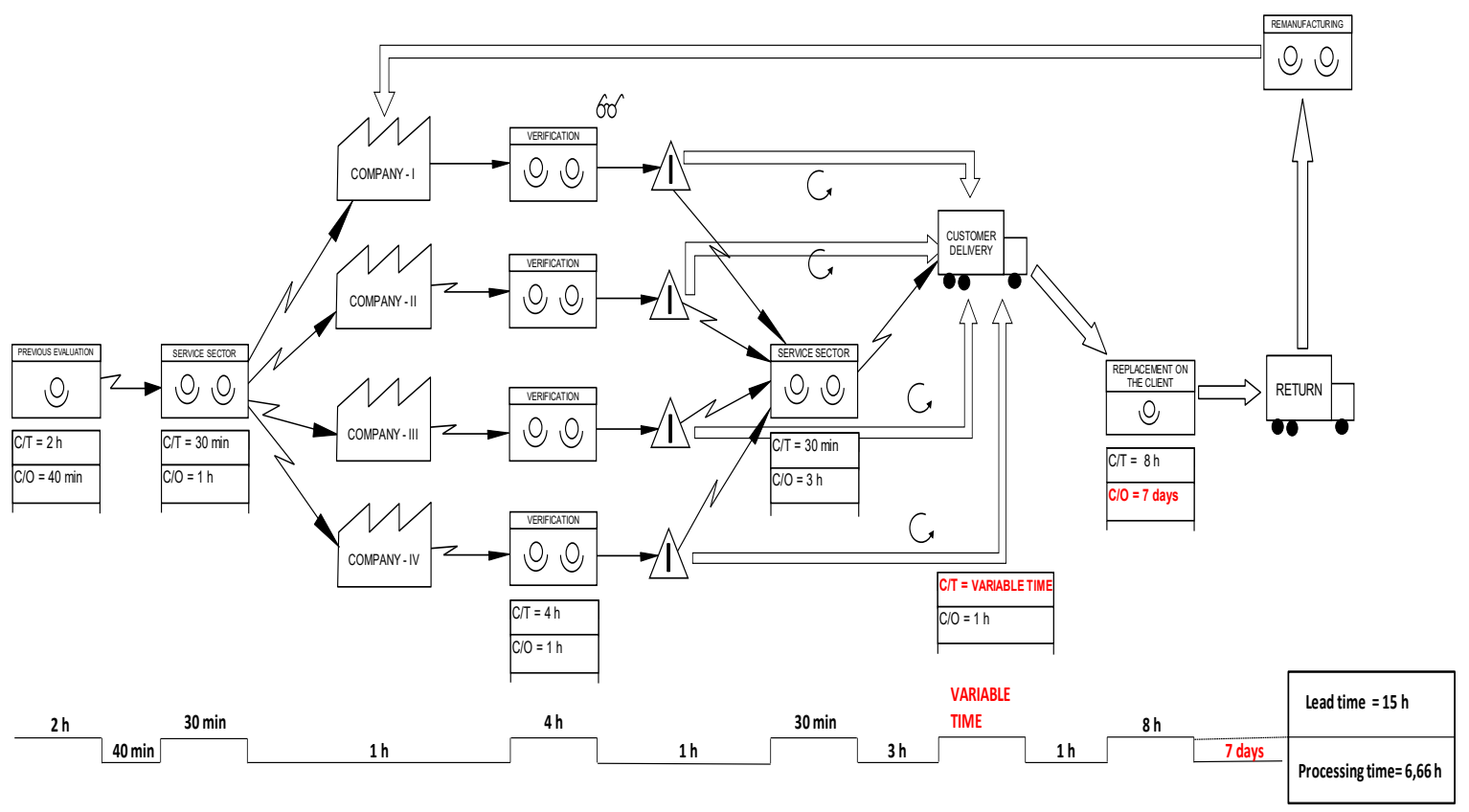

Figure 5. Current State Map

Source: The authors' own (2017). 
From the critical point of view, an important aspect to be punctuated is the distinction between how the consultation is done in each of the stocks. As a rule, the Companies II, III and IV, assume greater efficiency from the point of view of the parts control, because it has their respective inventories in the management software, which speeds up the response time. However, Company I does not have the inventory of parts in the system; therefore, the consultation is done in loco in the inventory of parts, making the process time consuming.

In addition to the above, it is possible to characterize that the Companies II, III and IV have an inventory of new parts, whereas in Company I the parts can have two classifications: quick consultation or slow consultation.

The quick consultation is characterized by those parts that are allocated in conventional warehouses, that is, in addressed shelves, while the pieces of slow consultation are those that also make up the stock, but are allocated in equipment that, for some reason, were scrapped and therefore are intended for the removal of parts.

Therefore, it is reiterated that, in VMS, when considering the cycle time of this step, Company I was taken as the basis for the average time among the four companies.

Finally, a cause and effect relationship are established between the process chain constraint and the steps that do not add value, that is, the way the constraint causes negative reflexes during the flow, making it inefficient.

In this sense, inefficiency causes waste that affects the chain of processes. Negative impacts affect management guidelines and operational routines, corroborating Falconi's (2013) conceptions.

In order to eliminate steps that absorb resources, but do not add value, retaking the main theme of the study, the impact of the geographical decentralization of invetories as the main constraint and fragilizing the elements of the whole chain generates waste in the process, such as: the excessive movement of information; overloading of the employees involved; and, increased logistics costs.

As a consequence of the segregation of inventories, it is noted that there are impacts of these wastes on the flow of the value chain. In addition, the negative aspects generated, either in a punctual way in the value chain or in the macro context of the organization, compromise its growth in the market.

In this way, the geographical decentralization of inventories, from the macro point of view, generates impacts in the context of the organization's guidelines, such as: customer service policy; financial performance; and, organizational processes.
Besides, opportunities for improvement based on the established analyzes are identified in the next section; consequently, the future state map is proposed.

\subsection{Proposal to Improve the Process}

\subsubsection{Future State Map}

Regarding the strategic planning of companies, it is noted that, when listing the priorities at the time of the merger, the question of geographical location was not considered to the detriment of other factors of greater relevance, as for example, the know-how that companies had at the market before being acquired by the group.

Thus, the lean alternative presents itself as an efficient philosophy to propose redefinitions in the functions, departments and processes of the company, allowing it to contribute positively to the creation of value and, thus, to elucidate the inherent needs of the chain of processes.

Although the VSM application aims to map the process to make it leaner, it is noted that the map of the future state will continue, according to Womack et Jones (2003), in order to eliminate waste, with the same logical flow shown in Figure 4 , but lean.

In this way, Figure 6 represents the future state map as the main argument to eliminate residues that affect the current flow.

In agreement with the data contained in the map of Figure 6, Table 3 proposes to synthesize the information pertinent to the times of the future state map.

Table 3. Summary of future state map times

\begin{tabular}{|c|c|c|c|}
\hline Stage & Description & Cycle time (C/T) & Changeover time (C/O) \\
\hline 1 & Technician request & $2 \mathrm{~h}$ & $40 \mathrm{~min}$ \\
\hline 2 & Service departmanet & $30 \mathrm{~min}$ & $1 \mathrm{~h}$ \\
\hline 3 & Check inventory & $45 \mathrm{~min}$ & $1 \mathrm{~h}$ \\
\hline 4 & Service departmanet & & $1 \mathrm{~h}$ \\
\hline 5 & Transport & Variable time & 7 days \\
\hline 6 & Customer service & $8 \mathrm{~h}$ & Unvalued \\
\hline 7 & Transport & Unvalued & Unvalued \\
\hline 8 & Refurbished & Unvalued & Processing time $=3,66 \mathrm{~h}$ \\
\hline \multicolumn{2}{|c|}{ Lead time $=11,25 \mathrm{~h}$} & \multicolumn{3}{|c}{} \\
\hline
\end{tabular}

Source: The authors' own (2017).

The current map approach assumes that the analyzed process has times that impact on the performance of the routines of the group of companies. Thus, it is evident by the analysis that the greatest aggravation falls on step 4, check inventory. 


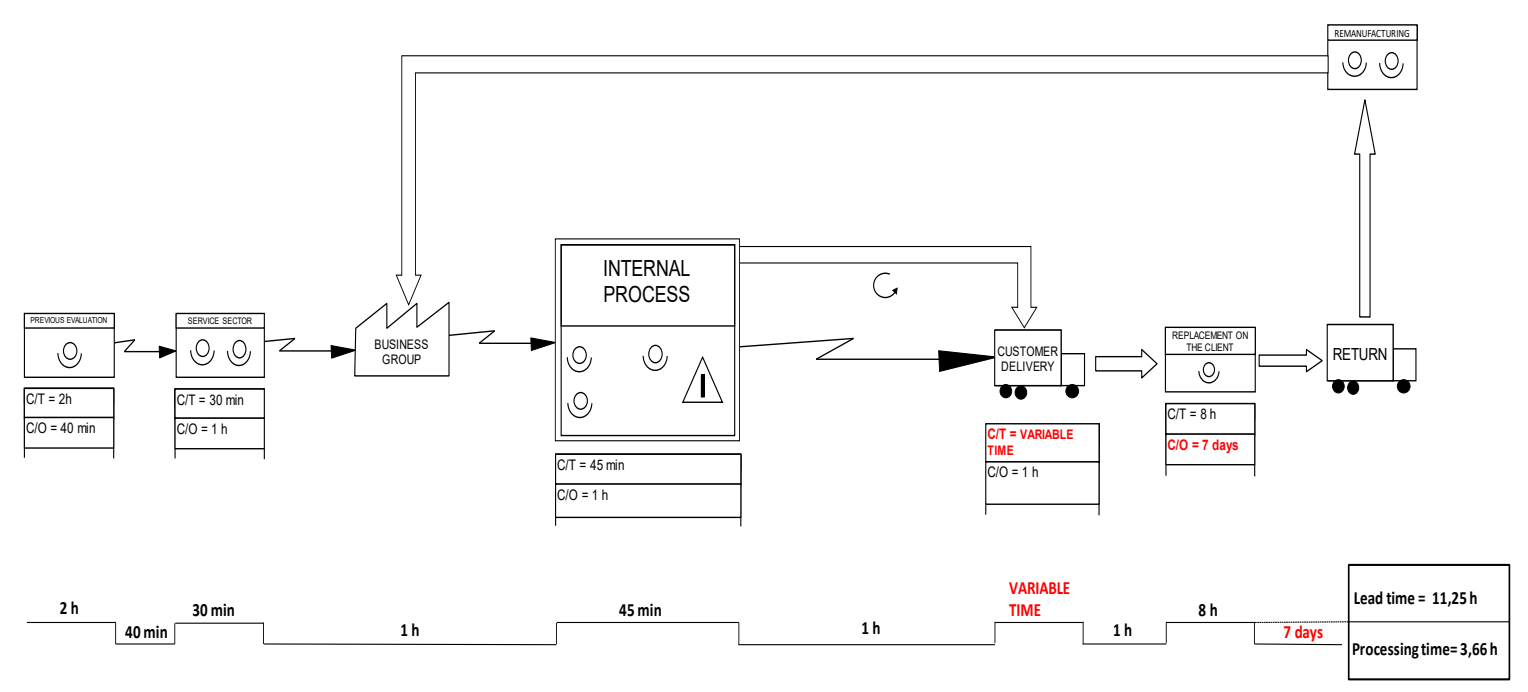

Figure 6. Future State Map

Source: The authors own (2017).

Thus, the main argument of the proposal to mitigate the wastes evidenced in the analysis of the map of the current state and, consequently, presented in future state map of Figure 6 is the unification between the services sector and the inventories.

As proposed, the analysis based on the theoretical foundation and perception about the waste of the process it is possible to stipulate that, in a centralized environment, the stages times will be reduced, according to Table 3.

The best way to understand how the future approach differs from the current approach is to analyze the contrast between Tables 2 and 3, in which Table 4 is presented.

Table 4. Comparison between lead time and processing time, current and future

\begin{tabular}{|c|c|}
\hline & \\
\hline Lead time $=15 \mathrm{~h}$ & Lead time $=11,25 \mathrm{~h}$ \\
\hline Processing time $=6,66 \mathrm{~h}$ & Processing time $=3,66 \mathrm{~h}$ \\
\hline
\end{tabular}

Source: The authors' own (2017).

Comparatively, in the current state map, the Lead Time and the Processing Time are $15 \mathrm{~h}$ and $6.66 \mathrm{~h}$, respectively. Whereas, in the future state map, the Lead Time and the Processing Time are $11.25 \mathrm{~h}$ and $3.66 \mathrm{~h}$, respectively. To demonstrate the efficiency, it is pointed out that, in the proposed VSM, there is a $25 \%$ reduction in the Lead Time, as well as a reduction of $45.05 \%$ in relation to Processing Time, a considerable gain.

In this way, time gains ensure an interesting competitive strategy. The main advantage lies in the following reasoning: the decrease in customer service time represents billing, good reputation, new orders, results for the company, jobs and compensation for employees.

Effectively, in relation to the wastes pointed out in the analysis of the current state map, there is substantial change in the flow of the steps. By eliminating the points that do not add value to the process, the goal isto establish a competitive advantage. In addition, the rationale for reducing waste is also simple: less waste, lower costs, more positive results for the company, more competitiveness, greater chances of maintaining and conquering markets, validating the approach of Carpinetti et al. (2011).

In addiction, from the point of view of logistic gains, in view of Ballou's (2006) approach, the unification of the services sector, together with inventories, allows mitigating logistics costs, such as: transportation, order processing and information systems. Thus, in contrast to the absence of a logistics strategy, as presented in section 4.3.1, the lack of information to control logistic activities generates negative impacts that directly influence costs and, consequently, affects the decision-making process.

In line with Falconi's (2013) conceptions, from the point of view of the work routine, the proposal aims to ensure that the more transparent the operation, the easier it will be for the whole team to share issues in terms of its management and improvement, once there was physical centralization of the service sector with the inventory. Thus, routine problems become more evident and detectable, facilitating their solutions.

Also, according to the Falconi (2013) concept and the approach presented in section 2.3, regarding the use of six sig- 
ma as an interface tool between the work routine and management by the guidelines - strategic / managerial level, it is pointed out that at applying the DMAIC as a practical tool, managing the guidelines, the points to be improved in the operational scope can be delineated.

Although the conception of the DMAIC cycle inherently has a continuous improvement character, which infers an ideal vision, it is evident that there is a distance between the organizational environment and the ideal scenario, being possible to approach it over time. Thus, only under a methodical and relentless application for continuous improvement can one approximate that ideal state.

Lastly, as a result of the identification of the points to be improved, the proposal of lean mapping requires a new conduct on the part of the company. In this sense, an auspicious organizational culture is created, in which the vision of value aggregation is increasingly propagated, thus increasing competitiveness, eliminating waste, reducing costs, increasing process efficiency and improving the relationship with the customer.

\section{CONCLUSIONS}

As noted by René Descartes in his Discourse on Method, a complex problem can and must be divided and solved into as many smaller parts as possible, so that the sum of the solutions of each of these small parts is still equal to the result of the problem initially proposed (Descartes, 2009; Falconi, 2013).

In consideration of the above approach, the essence of this work refers to the detailing of the stages through the VSM tool to optimize the time spent on the flow of the logistics process of sending parts to the field of the company, object of this study. It should be noted that the logical flow of the process in its eight stages remained unchanged after the construction of the proposal.

In this sense, lean mentality can be understood as much as a philosophy as a method for planning and controlling operations. More recently, global economic dynamism has allowed for open precedents, making it possible to explore the tool in other fields, other than the usual manufacturing. Therefore, this work develops an application focused on the service sector.

Complementarely, the value-stream mapping (VSM) and six sigma tools are used to support the analyzed application context and, consequently, the development of the improvement proposal.

It is also reiterated that the state of art analysis of the six sigma theory has shown that the use of the DMAIC tool in this work is applicable in two contexts: In the first one, as a method of conduction for the analysis of the processes pertinent to the case study; and, in the second context, as a tool for interfacing between the operational routine and management by the guidelines, in order to delineate the points of improvement in the operational scope.

Thus, at all times, the development of the case study was aimed to restrict the overview in which it was inserted, having as its objective the mapping of the value flow and improving the logistics process of the parts sent to the field, from the perspective of lean and six sigma philosophy.

Finally, the proposal to map the value flow applied to a service was proved to be efficient, mainly when analyzed under perspectives other than the usual ones. In other words, the auspicious understanding in terms of the theoretical tooling, presented by several authors in the literature, allowed us to infer meanings about application and, from a critical analysis, the proposal for improvement in said process was outlined. In addition, the current state map and the future state map are thus understood, when analyzed in contrast, as complementary and indispensable to the success of the implementation of improvements in the organization under study.

\section{REFERENCES}

Ballou, R. H. (2006), Gerenciamento da Cadeia de Suprimento/Logística Empresarial, 5.ed., Bookman, Porto Alegre.

Bento, G. S. et al. (2016), A Influência da Integração do Fornecedor e da Adoção de Práticas Lean no Desempenho Operacional, In: XIX Simpósio de Administração da Produção, Logística e Operações Internacionais - SIMPOI, Departamento de Administração da Produção e de Operações, FGV-EAESP, São Paulo, SP.

Beuren, I. M. (org.) (2006), Como Elaborar Trabalhos Monográficos em Contabilidade: teoria e prática, 3.ed., Atlas, São Paulo.

Calado, R. D. (2011), Método de Diagnóstico de Empresa: uma abordagem segundo os princípios Lean, Tese de Doutorado em Engenharia Mecânica, Faculdade de Engenharia Mecânica, Universidade Estadual de Campinas, Campinas-SP.

Carpinetti, L. C. R. et al. (2011), Gestão da Qualidade ISO 9001:2008: princípios e requisitos, Atlas, São Paulo, SP.

Carvalho, R, S. (2011), Implantação de Sistema de Gestão da Qualidade: um estudo de caso em uma importadora de medicamentos, In: VII Congresso Nacional de Excelência em Gestão - CNEG, Laboratório de Tecnologia, Gestão de Negócios e Meio Ambiente, Universidade Federal Fluminense, Niterói, RJ.

Cooper, D. R.; Schindler, P. S. (2016), Métodos de Pesquisa em Administração. 12.ed. Bookman, Porto Alegre. 
Brazilian Journal of Operations \& Production Management Volume 14, Número 4, 2017, pp. 556-566 DOI: 10.14488/BJOPM.2017.v14.n4.a11
Corrêa, H. L.; Gianesi, I. G. (1993), Just in Time, MRP II e OPT: um enfoque estratégico, 2. ed. Atlas, São Paulo.

Cruz, L.; Monteiro, M. (2015), Alinhando Velocidade, Qualidade e Rendimento: proposição de um modelo para aplicação conjunta das aordagens Lean, Seis Sigma e Teoria das Restrições (TOC) através de um roteiro prático, In: XI Congresso Nacional de Excelência em Gestão - CNEG, Universidade Federal Fluminense, Niterói, RJ.

Dahlgaard, J. J.; Dahlgaard-Park, S. M. (2006), "Lean Production, Six Sigma Quality, TQM and Company Culture", The TQM Magazine, Vol. 18, No. 3, pp. 263-281.

Descartes, R. (2009), Discurso do Método, 2. ed. Martins Fontes, São Paulo, SP.

Falconi, V. (2013), O Verdadeiro Poder, 2. ed. Falconi Editora, Nova Lima.

Fitzsimmons, J. A.; Fitzsimmons, M. J. (2014), Administração de Serviços: operações, estratégias e tecnologia da informação, 7. ed. Bookman, Porto Alegre.

Ghinato, P. (1997), Sistema Toyota de Produção: mais do que simplesmente Just-In-Time, Editora Universidade de Caxias do Sul, Caxias do Sul.

Gil, A. C. (2009), Estudo de Caso, Atlas, São Paulo, SP.

Gil, A. C. (2016), Como Elaborar Projetos de Pesquisa, 5.ed., Atlas, São Paulo, SP.

Gray, D. E. (2012), Pesquisa no Mundo Real, 2.ed., Penso, Porto Alegre.

Hair Junior, J. F. et al. (2005), Fundamentos de Métodos de Pesquisa em Administração, Bookman, Porto Alegre, 2005.

Holweg, M. (2007), "The Genealogy of Lean Production", Journal of Operations Management, Vol. 25, pp. 420-437.

Kerzner, H. (2011), Gerenciamento de Projetos: uma abordagem sistêmica para planejamento, programação e controle, 10.ed., Blucher, São Paulo, SP.

Leite, M. D.; Filho, F. R. J. (2009), "Alinhando Projetos à Estratégia de Negócios", In: V Congresso Nacional de Excelência em Gestão - CNEG, Universidade Federal Fluminense, Niterói, RJ.

Machado, M. C. (2006), Princípios Enxutos no Processo de Desenvolvimento de Produtos: proposta de uma metodologia para implementação, Tese de Doutorado em Engenharia de Produção, Escola Politécnica, Universidade de São Paulo, São Paulo, SP.

Matthew, P.; Spedding, T. (2010), "The Evolution of Lean Six Sigma", International Journal of Quality \& Reliability Management, Vol. 27, No. 2, pp. 138-155.

Oliveira, D. P. R. (2013), Administração de Processos: conceitos, metodologia, práticas, 5. ed, Atlas, São Paulo, SP.
Oliveira, J. A. et al. (2011), "Um Estudo sobre a Utilização de Sistemas, Programas e Ferramentas da Qualidade em Empresas do Interior de São Paulo", Produção, Vol. 21, No. 4, pp. 708-723.

Pacheco, D. A. J. (2014), "Teoria das Restrições, Lean Manufacturing e Seis Sigma: limites e possibilidades de integração", Produção, Vol. 24, No. 4, pp. 940-956.

Rahani, Ar; Al-Ashraf, M. (2012), "Production Flow Analysis through Value Stream Mapping: a leanmanufacturing process case study", In: International Symposium on Robotics and Intelligent Sensors - IRIS 2012, Procedia Engineering, 41, p. 1727-1734, Kuching, Sarawak, Malaysia.

Rezende Júnior, J. M. (2015), “Aplicação da Metodologia Lean Six Sigma em Processo de Análise e Compilação de Registros Industriais", In: XI Congresso Nacional de Excelência em Gestão - CNEG, Universidade Federal Fluminense, Niterói, RJ.

Rother, M; Shook, J. (2012), Aprendendo a Enxengar: mapeando o fluxo de valor para agregar valor e eliminar o desperdício, Lean Institute Brasil, São Paulo, SP.

Shah, R.; Ward, P. T. (2003), "Lean Manufacturing: context, practice bundles, and performance", Journal of Operations Management, Vol. 21, No. 2, pp. 129-149.

Sharma, U. (2003), "Implementing Lean Principles with the Six Sigma Advantage: how a battery company realized significant improvements", Journal of Organizational Excellence, Vol. 22, No. 3, pp. 43-52.

Shingo, S. (1996), O Sistema Toyota de Produção do Ponto de Vista da Engenharia de Produção, Bookman, Porto Alegre.

Slack, N. et al. (2009), Administração da Produção, 3.ed., Atlas, São Paulo, SP.

Sundar, R. et al. (2014), "A Review on Lean Manufacturing Implementation Techniques", In: 12th Global Congress on Manufacturing and Management - GCMM 2014, Procedia Engineering, 97, p.1875-1885, Vellore, India.

Tapping, D.; Shuker, T. (2010), Lean Office: gerenciamento do fluxo de valor para áreas administrativas -8 passos para planejar, mapear e sustentar melhorias lean nas áreas administrativas, Leopardo, São Paulo, SP.

Wee, H. M.; Wu, S. (2009), "Lean supply chain and its effect on product cost and quality: a case study on Ford Motor Company", Supply Chain Management: An International Journal, Vol. 14, No. 5, pp.335-341.

Womack, J. P. et al. (1992), A Máquina que Mudou o Mundo, Campus, Rio de Janeiro, RJ.

Womack, J. P.; Jones, D. T. (2003), Lean Thinking: banish waste and create wealth in your corporation, Free Press, New York. 